\title{
Salinity influences disease-induced mortality of the oyster Crassostrea gigas and infectivity of the ostreid herpesvirus 1 (OsHV-1)
}

\author{
Marine Fuhrmann ${ }^{1}$, Bruno Petton ${ }^{2}$, Virgile Quillien ${ }^{1}$, Nicole Faury ${ }^{3}$, \\ Benjamin Morga ${ }^{3}$, Fabrice Pernet ${ }^{1, *}$ \\ ${ }^{1}$ Ifremer/ LEMAR UMR 6539, Technopole de Brest-Iroise, 29280 Plouzané, France \\ ${ }^{2}$ Ifremer/ LEMAR UMR 6539, Presqu'île du vivier, 29840 Argenton, France \\ ${ }^{3}$ Ifremer/ Laboratoire de Génétique et Pathologie, Avenue de Mus de Loup, 17390 La Tremblade, France
}

\begin{abstract}
Mortality of young Pacific oysters Crassostrea gigas associated with the ostreid herpesvirus 1 (OsHV-1) is occurring worldwide. Here, we examined for the first time the effect of salinity on OsHV-1 transmission and disease-related mortality of C. gigas, as well as salinityrelated effects on the pathogen itself. To obtain donors for OsHV-1 transmission, we transferred laboratory-raised oysters to an estuary during a disease outbreak and then back to the laboratory. Oysters that tested OsHV-1 positive were placed in seawater tanks $\left(35 \%, 21^{\circ} \mathrm{C}\right)$. Water from these tanks was used to infect naïve oysters in 2 experimental setups: (1) oysters acclimated or nonacclimated to a salinity of $10,15,25$ and $35 \%$ and (2) oysters acclimated to a salinity of $25 \%$; the latter were exposed to OsHV-1 water diluted to a salinity of 10 or $25 \%$. The survival of oysters exposed to OsHV-1 water and acclimated to a salinity of $10 \%$ was $>95 \%$, compared to only 43 to $73 \%$ survival in oysters acclimated to higher salinities (Expt 1), reflecting differences in the levels of OsHV-1 DNA and viral gene expression (Expts 1 and 2). However, the survival of their nonacclimated counterparts was only $23 \%$ (Expt 2), and the levels of OsHV-1 DNA and the expression of 4 viral genes were low (Expt 1). Thus, OsHV-1 may not have been the ultimate cause of mortality in non-acclimated oysters weakened by a salinity shock. It appears that reducing disease risk by means of low salinity is unlikely in the field.
\end{abstract}

KEY WORDS: Bivalve $\cdot$ Herpesviridae $\cdot$ Infection · Disease transmission · Risk analysis

\section{INTRODUCTION}

Since 2008, massive mortality events of young Pacific oysters Crassostrea gigas have been reported in France (Miossec et al. 2009, EFSA AHAW 2010, Barbosa Solomieu et al. 2015, Pernet et al. 2016). These mortality events are associated with the infection of oysters with a newly described genotype $(\mu \mathrm{Var})$ of ostreid herpesvirus 1 (OsHV-1) (Segarra et al. 2010). A causal relationship between OsHV-1 and oyster mortality has been established (Schikorski et al. 2011, EFSA AHAW 2015). This virus is now dis-

\footnotetext{
${ }^{*}$ Corresponding author: fabrice.pernet@ifremer.fr
}

tributed along the European coastline from Portugal to Scandinavia, and closely related variants have been detected in Australia, New Zealand and Asia (Barbosa Solomieu et al. 2015, EFSA AHAW 2015, Pernet et al. 2016). OsHV-1 now poses a major challenge for Pacific oyster production around the world.

Oysters are grown in estuaries and bays, where they are often exposed to wide salinity fluctuations caused by evaporation, rainfall and inflow from rivers. Salinity may play a role in OsHV-1 transmission and disease development, as reported for other diseases of marine invertebrates (Haskin \& Ford 1982, Ragone

() The authors 2016. Open Access under Creative Commons by Attribution Licence. Use, distribution and reproduction are unrestricted. Authors and original publication must be credited. 
Calvo et al. 1998, Brothers et al. 2000, Reid et al. 2003, Liu et al. 2006, Ford et al. 2012, Soudant et al. 2013). Indeed, salinity influences host-pathogen interactions by acting directly on the pathogen, the host or both, and it can modulate the severity of the disease.

Most pathogens are susceptible to salinity because of their ionic permeability. For instance, decreasing salinity damages protozoan parasites because they are unable to regulate their cell volume (Ford \& Haskin 1988, Burreson et al. 1994). Salinity also affects the occurrence and persistence of bacteria in the aquatic environment. For instance, the optimal salinity for the growth of pathogenic strains of Vibrio splendidus and $V$. aestuarianus is approximately $20 \%$ (Vezzulli et al. 2015). To our knowledge, no information is available on the precise effects of salinity on eukaryotic marine viruses, but for viruses that infect bacteria, salinity influences viral adhesion to the hosts or genome injection by altering their envelope or capsid (Cordova et al. 2003, Kukkaro \& Bamford 2009, Mojica \& Brussaard 2014).

The immune functions of bivalves are influenced by salinity with direct effects on the viability and activity of haemocytes (Matozzo \& Marin 2011, Carregosa et al. 2014). Furthermore, the energy allocated for acclimation to salinity can impair defenses against pathogens (Gilles 1972, Shumway 1977, Shumway et al. 1977, Neufeld \& Wright 1996). Thus, a change in salinity may increase host susceptibility to pathogens.

The aim of this study was to investigate the effect of salinity on disease transmission and the related mortality of C. gigas. Specifically, we examined the effect of salinity (1) on both the host and pathogens and (2) on the pathogens only. For both experiments, oysters were transferred to an estuary during a disease outbreak and then returned to the laboratory. Infected oysters were placed in tanks, and the surrounding seawater was used as a source of infection (SI). The SI was then (1) directed towards recipient oysters held at 4 salinities with or without prior acclimation or (2) brought to a salinity of 10 or $25 \%$ and directed towards recipient oysters maintained at 25\%. Overall, this method, which has been used in many previous studies (Petton et al. 2013, 2015a,b, Tamayo et al. 2014, Lassudrie et al. 2015, Lemire et al. 2015, Pernet et al. 2015), reproduces the natural infection process and takes into account the fact that OsHV-1 triggers oyster mortality, although other microorganisms can also play a role (Saulnier et al. 2010, Lemire et al. 2015, Petton et al. 2015b).

\section{MATERIALS AND METHODS}

\section{Animals}

The 4 mo old oysters used in Expts 1 and 2 were taken from 2 cohorts, produced in 2014 and 2015, respectively, according to Petton et al. (2015a). Adults originating from Fouras (France, $46^{\circ} 00^{\prime} 43.2^{\prime \prime} \mathrm{N}$, $\left.1^{\circ} 07^{\prime} 02.9^{\prime \prime} \mathrm{W}\right)$ were moved to the Ifremer marine station in Argenton (48 48' 24.49" N, $3^{\circ} 0^{\prime} 22.84^{\prime \prime} \mathrm{W}$ ) for conditioning in January 2014 and March 2015 for Expts 1 and 2, respectively. These oysters were maintained at $17^{\circ} \mathrm{C}$ in $500 \mathrm{l}$ flow-through tanks. Fertilization was achieved on 11 March 2014 (Expt 1) and on 28 April 2015 (Expt 2) by stripping the gonads. The embryos developed in $150 \mathrm{l}$ tanks at $21^{\circ} \mathrm{C}$ for $48 \mathrm{~h}$, and D-larvae were transferred to flow-through rearing systems at $25^{\circ} \mathrm{C}$. After $15 \mathrm{~d}$, competent larvae were collected and allowed to settle in downwellers. The entire rearing cycle was conducted in UVsterilized, $1 \mu \mathrm{m}$ filtered seawater enriched with living phytoplankton (Petton et al. 2015a). At the onset of both experiments (17 July 2014 and 7 August 2015), the total body mass of oysters was similar at $0.8 \pm$ $0.2 \mathrm{~g}$ (mean $\pm \mathrm{SD}$ ).

During the experiments, oysters were fed with a mixture of Chaetoceros muelleri (CCAP 1010/3) and Tisochrysis lutea (CCAP 927/14) (1:1 in dry weight). Food concentration was ca. $1300 \mu^{3} \mu^{-1}$ of microalgae at the outlet of the rearing tanks. Seawater was sampled daily at the inlet and outlet of each experimental tank to determine phytoplankton consumption. Cell concentrations were measured using an electronic particle counter (Multisizer 3) equipped with a $100 \mu \mathrm{m}$ aperture tube. Salinity, temperature, $\mathrm{pH}$ and oxygen were controlled daily with the WTW probes cond340, xi3101, pH3310 and FDO 925, respectively. Each tank was lightly bubbled to maintain oxygen levels between 85 and $100 \%$ of saturation.

\section{Method of infection}

The method of infection was a modified procedure from Petton et al. (2015a). Oysters were transferred on 22 July 2014 (Expt 1) and 6 August 2015 (Expt 2) to a farming area of the Bay of Brest $\left(48^{\circ} 20^{\prime} 06.19^{\prime \prime} \mathrm{N}\right.$, $\left.4^{\circ} 19^{\prime} 06.37^{\prime \prime} \mathrm{W}\right)$ where oyster mortality was occurring. The salinity was $34 \%$. After a week of exposure to field conditions, few dead oysters were observed, and the remaining live individuals were moved back to the Ifremer facilities in Argenton. These oysters tested positive for the OsHV-1 $\mu$ Var strain, and the 
level of virus DNA was $1.9 \times 10^{9} \pm 1.6 \times 10^{9}$ copies $\mathrm{mg}^{-1}$ fresh weight (mean $\pm \mathrm{SD}_{i} \mathrm{n}=3$ pools of 15 oysters); they were therefore considered useful as OsHV-1 donors and placed in $45 \mathrm{l}$ flow-through tanks at $35 \%$ and $21^{\circ} \mathrm{C}$ (Petton et al. 2013). The seawater surrounding the donors was used as the SI.

For Expt 1, the SI was connected by flexible tubes fitted inside a peristaltic pump to $45 \mathrm{l}$ tanks $(\mathrm{n}=12)$, which contained the recipient oysters at 4 salinities. The other 12 tanks were not connected to the SI and were used as controls. For each tank, the water flow from the SI was $11 \%$ of the total water flow $\left(12 \mathrm{l} \mathrm{h}^{-1}\right)$. The water input from the SI was arrested on Day 6, when the recipients exhibited mortality. For Expt 2, the SI was connected to $45 \mathrm{l}$ tanks $(\mathrm{n}=6)$, which contained water at either $10 \pm 0.7 \%$ (low-salinity tanks, $\mathrm{n}=3$ ) or $25.1 \pm 0.4 \%$ (control tanks, $\mathrm{n}=3$ ). These salinities were obtained by mixing seawater from the SI $(35 \%)$ with fresh water. These tanks were then connected to $45 \mathrm{l}$ tanks $(\mathrm{n}=6)$ containing recipient oysters maintained at $25.4 \pm 0.2 \%$. In each tank, the water flow from the SI was maintained at $11 \%$ of the total water flow fixed at $6 \mathrm{l} \mathrm{h}^{-1}$ for $4 \mathrm{~d}$.

\section{Experimental design}

We first investigated the effect of 4 salinities (mean \pm SD: $10.2 \pm 0.4,15 \pm 0.8,24.9 \pm 0.4,35.4 \pm 0.2 \%$ o) encountered in the field (Fig. 1) on disease transmission and the subsequent mortality of Pacific oysters (Expt 1). These salinities were obtained by mixing $1 \mu \mathrm{m}$ filtered and UV sterilized seawater $(35 \%)$ with fresh water from the tap (chlorine level $<0.3 \mathrm{mg} \mathrm{l}^{-1}$ ). Between 17 and 28 July 2014, oysters were acclimated to each salinity in $45 \mathrm{l}$ tanks (Fig. 2, $\mathrm{n}=6$ tanks, 310 oysters $\operatorname{tank}^{-1}$ ). Filtration rate, i.e. the volume of microalgae consumed per gram of oyster per day, was measured daily in each tank using the following formula:

(1)

Filtration rate $\left(\mu \mathrm{m}^{3} \mathrm{~g}^{-1} \mathrm{~d}^{-1}\right)=\frac{\left(\left[\mathrm{cell}_{\text {inlet }}\right]-\left[\text { cell }{ }_{\text {outlet }}\right] \times \text { Waterflow }\right)}{\text { Biomass of oysters }}$ where the variables were the concentrations of microalgae at the inlet and outlet of the tank ([Cell inlet $\left._{\text {and }}\right]$ and $\left[\right.$ Cell $\left._{\text {outlet }}\right]$ in $\mu \mathrm{m}^{3}$ of algae per $\mu \mathrm{l}$ of seawater); the water flow in the rearing tank, which was maintained at $12 \mathrm{l} \mathrm{h}^{-1}$; and the biomass of oysters in each tank. On 28 July 2014 (Day 0), the biomass of acclimated

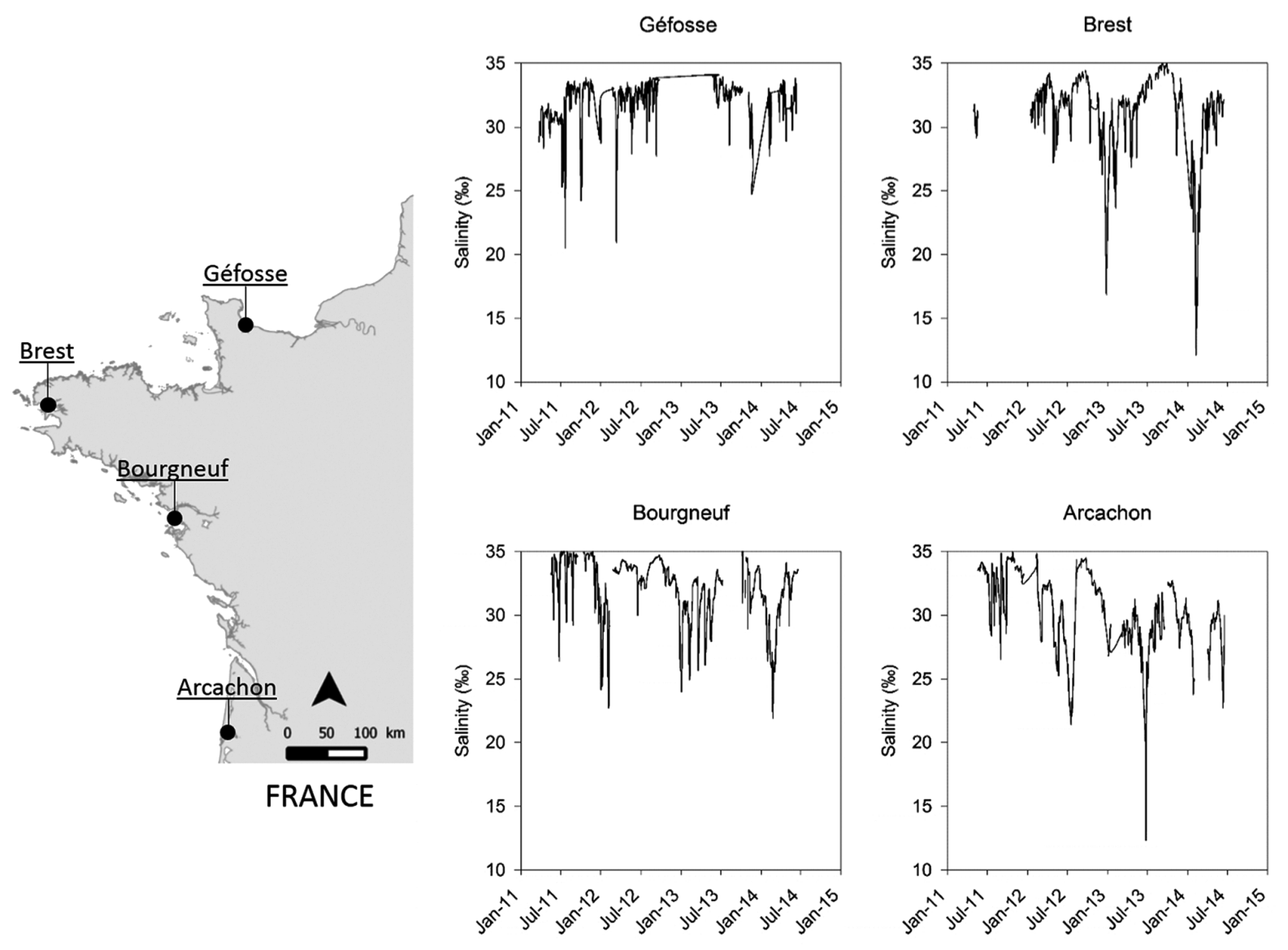

Fig. 1. Seawater salinities from January 2011 to June 2014 in 4 oyster farming areas along the French coast 


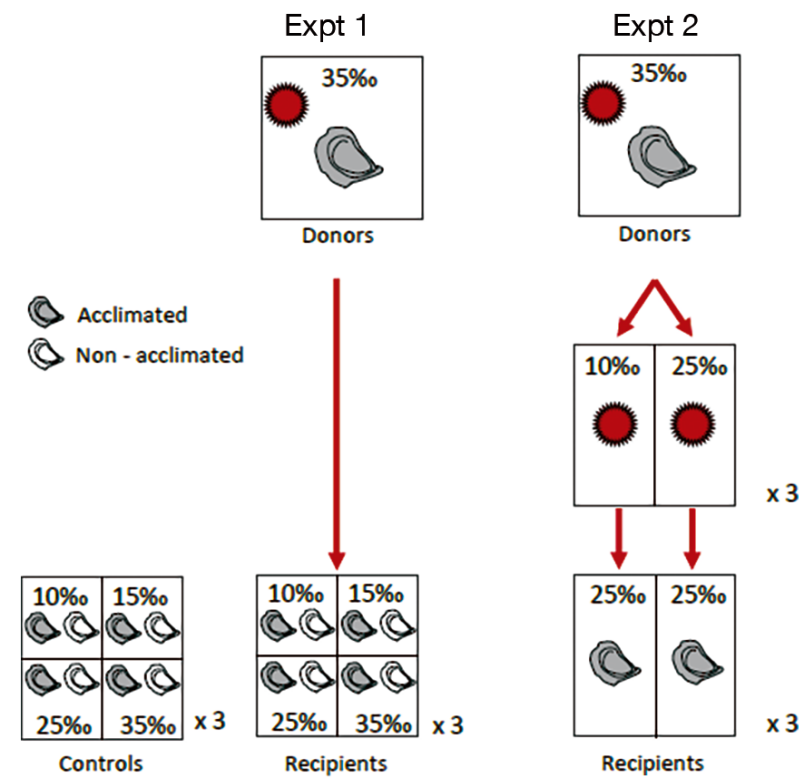

Fig. 2. Schematic of experimental designs. Expt 1: Study of the effect of salinity on disease transmission and related mortality of Pacific oysters Crassostrea gigas, in particular in the presence of ostreid herpesvirus OsHV-1 $\mu$ Var. We used 2 infection levels $\times 4$ salinity treatments $\times 3$ replicate tanks $\times 2$ acclimation levels (within tank). Expt 2: Study of the effect of salinity on pathogens, in particular on OsHV-1 $\mu$ Var. We used 2 salinity treatments $\times 3$ replicate tanks

oysters was standardized at ca. $160 \mathrm{~g}$ in each tank to remedy differences in the growth rates among the salinity treatments. In the same tanks, $160 \mathrm{~g}$ of nonacclimated oysters were added. Half of the tanks were connected for $6 \mathrm{~d}$ to the SI, and the other half were used as controls. Survival of recipient oysters was monitored daily for $17 \mathrm{~d}$, and dead oysters were removed from tanks.

We then investigated the effect of salinity on the infectivity of OsHV-1 (Expt 2). Between 7 and 13 August 2015, oysters were acclimated at 25\% in 451 tanks (Fig. 2, $\mathrm{n}=6$ tanks, 180 oysters tank $^{-1}$ ). On 13 August 2015 (Day 0), the biomass of acclimated oysters was standardized at ca. $150 \mathrm{~g}$ of total oyster biomass in each tank. The tanks were connected to the SI. Survival of recipient oysters was monitored daily for $14 \mathrm{~d}$, and dead oysters were removed from tanks.

Alive recipient oysters (15 for Expts 1 and 10 for Expt 2) were sampled in each tank on Days 0, 2 and 4 before the onset of mortality (Petton et al. 2013, 2015a). Whole tissues were removed from the shells, pooled together, flash frozen in liquid nitrogen and stored at $-80^{\circ} \mathrm{C}$. The oyster tissues were then ground in liquid nitrogen with a MM400 homogenizer (Retsch), and the resulting oyster powder was subsampled (30 mg of fresh weight) for quantification of OsHV-1 DNA and viral gene expression.

\section{OsHV-1 DNA quantification}

These analyses were conducted by the Laboratoire Départemental Vétérinaire de l'Hérault (Montpellier, France) using oyster powder homogenized in sterile artificial seawater (Pepin et al. 2008). Total DNA was then extracted with a QIAamp tissue mini kit (Qiagen) according to the manufacturer's protocol. The extract was stored at $-20^{\circ} \mathrm{C}$ before detection and quantification according to a real-time PCR protocol based on SYBR@ Green chemistry (Pepin et al. 2008) with specific primers validated by Webb et al. (2007). The results were expressed as the number of OsHV-1 DNA copies per mg of wet tissue.

\section{OsHV-1 gene expression}

Total RNA was extracted with EXTRACT-ALL® (Eurobio) according to the manufacturer's recommendation, and $20 \mu \mathrm{g}$ of extracted RNA were then removed from the genomic DNA using a DNase $\operatorname{Max}^{\mathrm{TM}}$ Kit (MO Bio). The RNA quantity and quality were determined with a NanoDrop 2000 spectrophotometer (Ambion $®$ ). A No-RT was then performed to confirm the absence of genomic DNA. First-strand cDNA synthesis was performed using the SuperScript III First-Strand Synthesis System (Invitrogen) on $500 \mathrm{ng}$ of treated RNA.

The OsHV-1 genome has $207439 \mathrm{bp}$ and contains 124 unique genes (Davison et al. 2005). In this study, open reading frames $72,75,87$ and 117 were selected from Segarra et al. (2014). These genes encode for a membrane protein, a dUTPase enzyme, an apoptosis inhibitor and a ring finger protein (Davison et al. 2005, Segarra et al. 2014). Gene expression was expressed as a delta threshold cycle number $(\mathrm{Ct})$ and calculated using the following formula: $\mathrm{Ct}$ viral gene - Ct house-keeping gene (elongation factor).

Real-time (RT) quantitative PCRs were performed with an Mx3005P Thermocycler sequence detector (Agilent). The forward and reverse primers used for this study were described by Segarra et al. (2014). Amplification reactions were done in duplicate in a total volume of $20 \mu \mathrm{l}$. Each well contained $5 \mu \mathrm{l}$ of cDNA solution (1/30, diluted in nuclease-free water), $10 \mu \mathrm{l}$ of Brilliant ${ }^{\circ}$ SYBR $®$ Green III PCR mix (Agilent), $2 \mu \mathrm{l}$ of forward and reverse primers $(3 \mu \mathrm{M})$ and $1 \mu \mathrm{l}$ of distilled water. The thermal cycling conditions for the PCRs were $3 \mathrm{~min}$ at $95^{\circ} \mathrm{C}$ followed by 40 amplification cycles at $95^{\circ} \mathrm{C}$ for $5 \mathrm{~s}$ and $60^{\circ} \mathrm{C}$ for $20 \mathrm{~s}$. To ensure the specificity of the primers used, melting curves were plotted $\left(55-95^{\circ} \mathrm{C}\right)$. For each $\mathrm{qPCR}_{\text {, }}$ 
negative controls were included to rule out DNA contamination.

\section{Statistical analyses}

\section{ANOVAs}

The differences in oyster total body mass at the end of the acclimation period among the salinity treatments were analysed by ANOVA (Expt 1). Mixeddesign ANOVAs were performed to assess differences in (1) the filtration rate depending on salinity (4 levels, main plots) and acclimation time (8 levels, subplots); (2) the levels of OsHV-1 DNA and viral gene expression in oysters, depending on (1) salinity and infection $(4 \times 2$ levels, main plot $)$, acclimation (2 levels, subplots), time (for DNA only, 2 levels, subsubplots) (Expt 1) and (2) salinity (2 levels, main plots) and time (2 levels, subplots) (Expt 2). Differences in viral gene expression among the salinity treatments were analysed by ANOVA (Expt 2).

The unit of replication was the tank in which the salinity and infection treatments were applied. All mutual interactions among the factors were tested, and Tukey's HSD was used as a post hoc test. The normality of residuals and homogeneity of variances were graphically checked, and the data were log $(x+1)$ transformed where necessary. ANOVAs were carried out using R (www.R-project.org/).

\section{Survival analysis}

Nonparametric estimates of the survivor function were computed according to Kaplan \& Meier (1958). Survival time was measured as days from the onset of the experiment (Day 0) when oysters were exposed to the SI. The data were read as the number of dead animals within each tank on each day. Survival curves of exposed oysters were plotted and compared among the salinity treatments.

In Expt 1, the survival time curves of oysters connected to the SI were compared using the Cox regression model (Cox 1972) after adjustment for the effect of salinity and acclimation. The survival of control oysters (not exposed to the SI) was not included in the statistical models because it was always
$>95 \%$. The proportionality of hazards (PH) was checked with martingale residuals (Lin et al. 1993, Lee \& Wang 2013). Because the PH assumption was violated, time-dependent covariates representing the interaction of the original covariates and time were added to the model. Time $(t)$ was defined as dichotomous: $t \leq 6 \mathrm{~d}$ or $t>6 \mathrm{~d}$. Custom hazard ratios were produced by means of contrasts. Cox regression was conducted using SAS 9.4 (SAS Institute).

\section{RESULTS}

\section{Salinity modulates host-pathogen interaction (Expt 1)}

Prior to the experiment, the filtration rates of oysters at 10 and $15 \%$ were initially lower than those of oysters at $25-35 \%$. The rates then increased during the first 2 to $6 \mathrm{~d}$ of acclimation until reaching the filtration rates of oysters at 25-35\% (Fig. 3A, Table S1 in the Supplement at www.int-res.com/articles/suppl/ q008p543_supp.pdf). At the end of the acclimation period, the total body mass of oysters at different salinity levels was ranked as follows: $10<15<25=$ $35 \%$ (Fig. 3B, Table S2 in the Supplement). At 10\%, the oysters did not grow ( $p=0.103)$.

Survival of control oysters was $99.1 \pm 1.9 \%$ (mean \pm SD) irrespective of salinity and acclimation treatments. Consequently, only oysters exposed to the SI were considered in this section.

At the end of the experiment, the survival of oysters exposed to the SI and acclimated at $10 \%$ was higher $(95.8 \%)$ than that of oysters held at 15, 25 and $35 \%$,
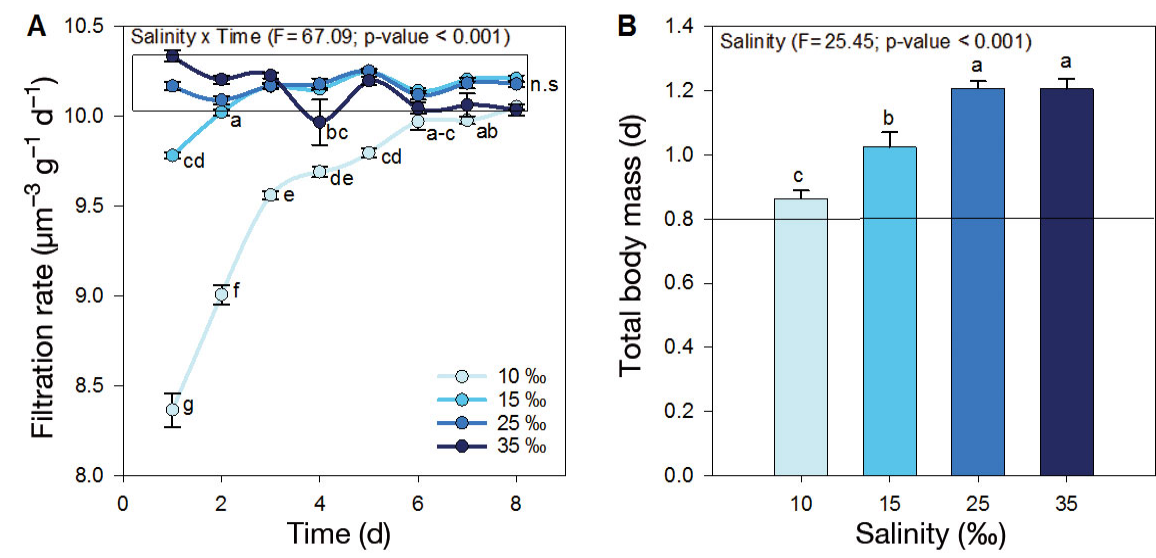

Fig. 3. (A) Filtration rate of Pacific oysters Crassostrea gigas during acclimation to salinity. (B) Body mass of oysters as a function of salinity after $11 \mathrm{~d}$ of acclimation (Expt 1). Data are means \pm SE between replicates $(n=6)$. Letters indicate significant differences. Filtration rate was $\log (x+1)$ transformed 

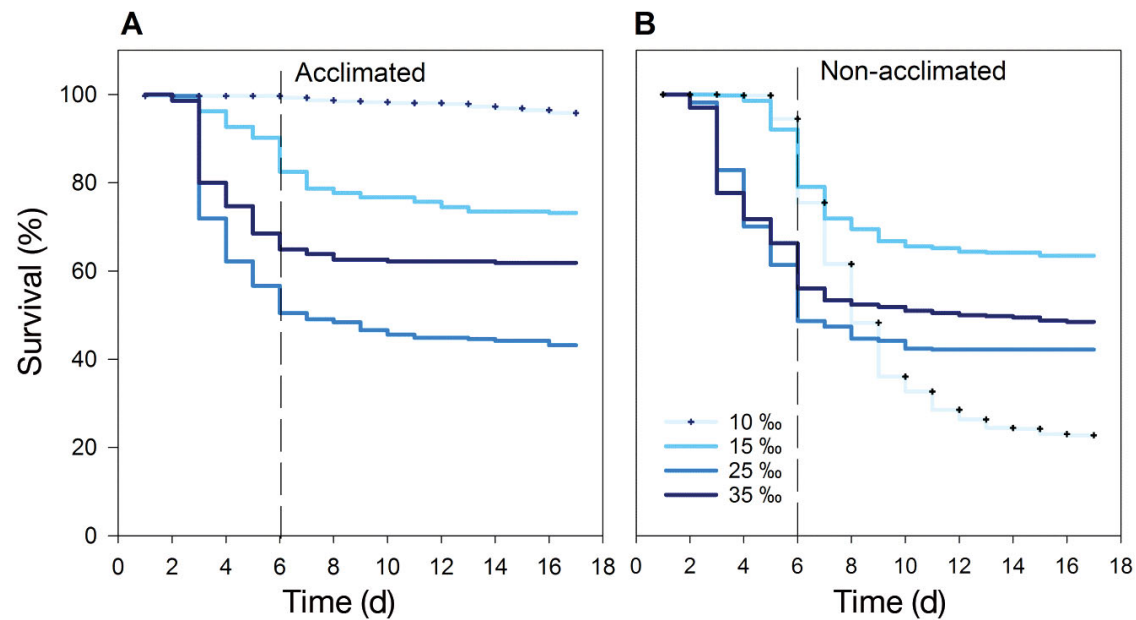

Fig. 4. Survival of Pacific oysters Crassostrea gigas exposed to the source of infection at 4 salinities (A) with or (B) without prior acclimation. Survival time was measured as days from the onset of exposure to the source of infection

where survival was $73.2,43.2$ and $61.9 \%$, respectively (Fig. 4A). In contrast, when oysters were exposed to the SI without prior acclimation to the salinity, their survival at $10 \%$ was markedly lower $(22.8 \%)$ than at 15,25 and $35 \%$, where survival was $63.5,42.2$ and $48.5 \%$, respectively (Fig. 4B).

During the first $6 \mathrm{~d}$, the oyster mortality hazard was ranked as $10<15<35<25 \%$ or $10<15<25=35 \%$ o for acclimated and non-acclimated oysters, respectively (Table S3 in the Supplement). Between 7 and $17 \mathrm{~d}$, the mortality hazard in acclimated oysters remained fairly similar $(10<35<15<25 \%)$ to that observed between 0 and $6 \mathrm{~d}$. Overall, low salinity decreased the risk of mortality of acclimated oysters exposed to the SI. This was not the case in non-acclimated oysters, where the mortality hazard at $10 \%$ was 3 to 4 times higher than that at $15-35 \%$ between 7 and $17 \mathrm{~d}$ (Table S3).

On Day 0, OsHV-1 DNA was not detected in recipient oysters. Salinity influenced the levels of OsHV-1 DNA in exposed oysters but not in controls on Days 2 and 4 (Fig. 5A, Table S4 in the Supplement). In fact, at $10 \%$, the level of OsHV-1 DNA in exposed oysters was as low as in the controls $\left(4.7 \times 10^{3}\right.$ copies $\left.\mathrm{mg}^{-1}\right)$, but it reached more than $10^{6}$ copies $\mathrm{mg}^{-1}$ at higher salinities. Viral gene expression in exposed oysters was ranked as $10<15=25=35 \%$, and at $10 \%$ it was as low as in the controls (Fig. 5B, Table S5 in the Supplement).

\section{Low salinity reduces OsHV-1 infectivity (Expt 2)}

When the SI was treated for $7 \mathrm{~h}$ at $10 \%$ before coming into contact with oysters at $25 \%$, survival of the oysters remained $100 \%$ (Fig. 6A). In contrast, when the SI was treated at $25 \%$ (control), survival decreased to $44.8 \%$ after $14 \mathrm{~d}$. The level of OsHV-1 DNA in oysters exposed to the SI treated at $10 \%$ was markedly reduced compared to that of controls (Fig. 6B, Table S6 in the Supplement). The levels of viral gene expression in oysters after the SI was treated at $10 \%$ were lower than that expressed after exposure to $25 \%$ (Fig. 6C, Table S7 in the Supplement).

\section{DISCUSSION}

The survival of oysters exposed to the SI and acclimated at $10 \%$ was always $>95 \%$, compared to only 43 to $73 \%$ at higher salinities. Concomitantly, the levels of OsHV-1 DNA and the expression of 4 viral genes in oysters were lower at $10 \%$ than at other salinities. Therefore, the high survival at $10 \%$ coincided with low levels of OsHV-1 DNA and viral gene expression. Although the effect of salinity on virus-bivalve interactions has never been investigated, it is known to influence other host-pathogen interactions in the marine environment. Indeed, low salinity reduces the disease risk and prevalence of protozoan parasites in oysters and clams (Andrews \& Wood 1967, Haskin \& Ford 1982, Ragone Calvo et al. 1998, Brothers et al. 2000, Soudant et al. 2013). We further investigated whether the increased survival of oysters acclimated at $10 \%$ exposed to the SI reflects changes in pathogen infectivity or in host physiology or both.

Low salinity $(10 \%)$ clearly reduced OsHV-1 infectivity because (1) the survival of oysters held at $25 \%$ 
and further exposed to the SI previously treated at $10 \%$ was $100 \%$, compared to only $45 \%$ in oysters exposed to the SI treated at $25 \%$, and (2) the levels of OsHV-1 DNA and the viral gene expression in oysters were much lower when the SI was treated at $10 \%$. Studies show that salinity influences the infectivity of bacteriophages by altering their structures and changing the adsorption rate to host cells (Mojica \& Brussaard 2014). It is likely that OsHV-1, as an enveloped virus (Renault et al. 2004, Davison et al. 2005), is particularly susceptible to changes in envi-
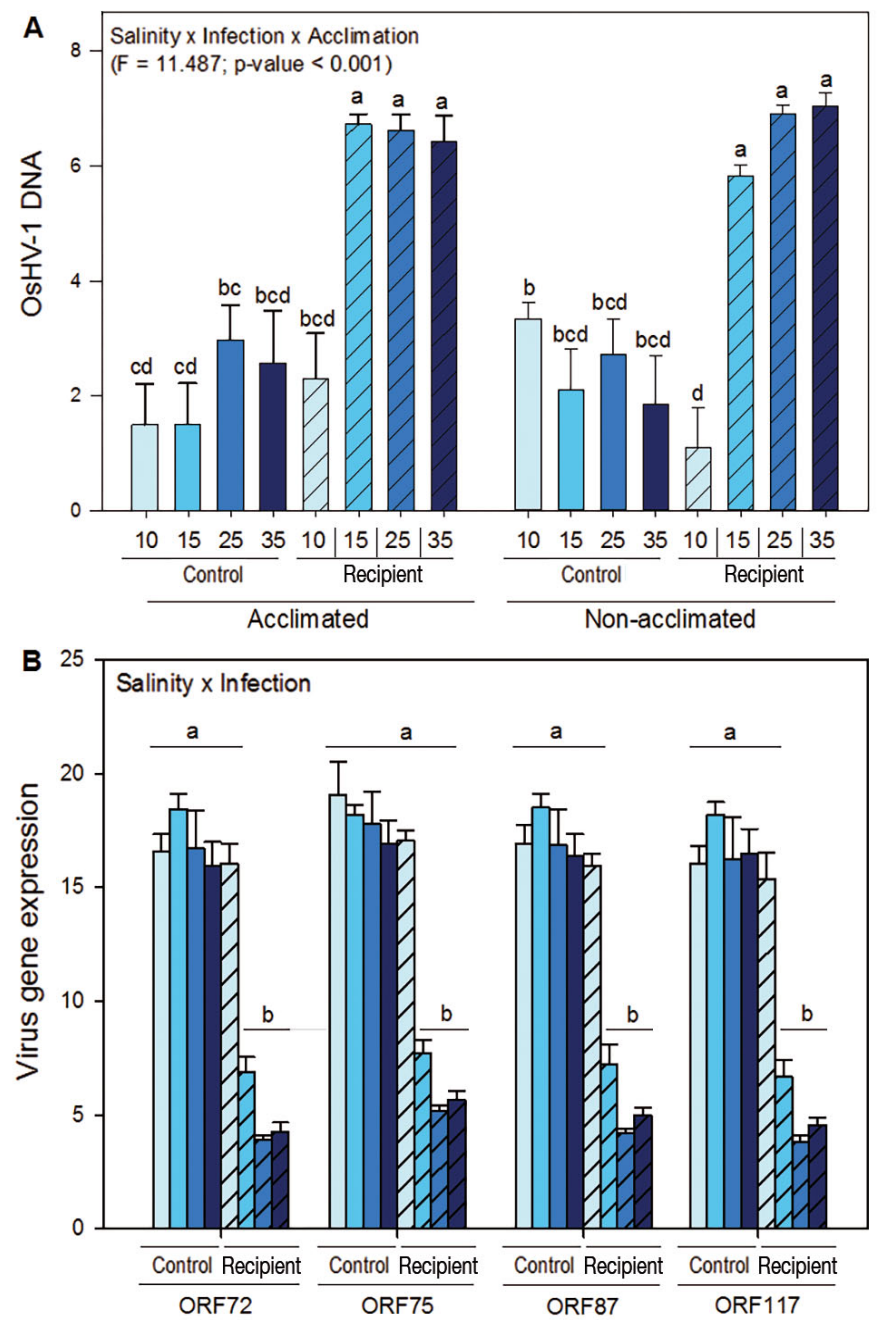

Fig. 5. (A) Quantification of OsHV-1 DNA, expressed as DNA copy numbers per mg of fresh weight and (B) virus gene expression as a delta threshold cycle number $(\mathrm{Ct})$ of OsHV-1 open reading frames (ORFs) relative to Pacific oyster Crassostrea gigas elongation factor in live oysters as a function of salinity, exposure to the source of infection and acclimation. Data are means $\pm \mathrm{SE}(\mathrm{n}=3$ tanks). For OsHV-1 DNA, data were $\log (x+1)$ transformed and are the means of Days 2 and 4 . The viral gene expression analyses were conducted on Day 2 only. Different letters indicate significant differences
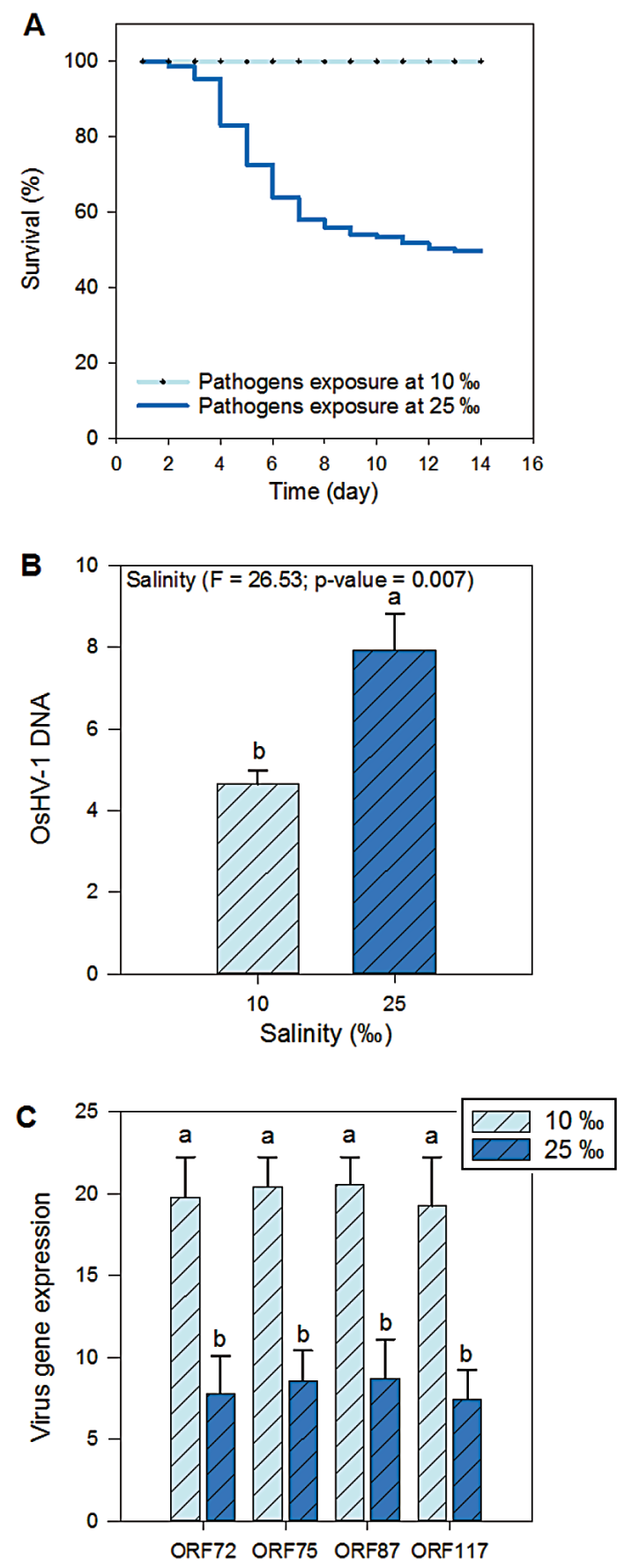

Fig. 6. (A) Survival of Pacific oysters Crassostrea gigas, (B) quantification of OsHV-1 DNA, expressed as DNA copies number per mg of fresh weight and $(\mathrm{C})$ virus gene expression as a delta threshold cycle number $(\mathrm{Ct})$ of OsHV-1 open reading frames (ORFs) relative to $C$. gigas elongation factor in live recipient oysters maintained at $25 \%$ and exposed to the source of infection previously treated at 10 and $25 \%$. Survival time was measured as days from the onset of exposure to the source of infection. Data are means \pm SE $(n=3$ tanks). For OsHV-1 DNA, the data were log $(x+1)$ transformed and are the means of Days 2 and 4. The gene expression analyses were conducted on Day 2 only. Different letters indicate significant differences 
ronmental parameters such as salinity. This type of virus is generally more susceptible to environmental changes than non-enveloped viruses (Lucas 2001, Kukkaro \& Bamford 2009).

Prior acclimation to salinity plays a major role in the host response to a pathogen. The survival of oysters exposed to the SI and acclimated at 10\% was always $>95 \%$, whereas the survival of their nonacclimated counterparts held in the same tanks was only $23 \%$. Nevertheless, the levels of OsHV-1 DNA and viral gene expression in these non-acclimated oysters were similar to those of controls and acclimated animals that showed no significant mortality. Therefore, OsHV-1 may not be the cause of mortality in these oysters. A more likely hypothesis is that another microorganism killed these animals simultaneously weakened by a salinity shock. In our study, donors were infected in the field where the OsHV-1induced mortality occurred, and they may have introduced a diversity of Vibrio species or other pathogens to the recipients (Lemire et al. 2015, Petton et al. 2015b). In addition, acute exposure to low salinity may have altered the defenses of oysters either directly by impairing their immunity (Matozzo \& Marin 2011, Carregosa et al. 2014, Knowles et al. 2014) or indirectly by causing the oysters to allocate energy to regulate intracellular osmotic concentrations (Gilles 1972, Shumway 1977, Shumway et al. 1977, Neufeld \& Wright 1996), thus compromising the defense response.

Oyster mortality began after only 2 to $3 \mathrm{~d}$ of exposure to the SI except for the non-acclimated animals at 10 and $15 \%$, in which it occurred after $6 \mathrm{~d}$. This delay may reflect salinity acclimation time. Indeed, bivalves exposed to an acute change in salinity first close their shells and reduce feeding (Pierce \& Greenberg 1972). This behaviour was observed during acclimation prior to the experiment. Considering that suspension feeding is the portal of entry for pathogens in bivalves (Ben-Horin et al. 2015), the reduction in the oyster feeding rate at low salinity may have decreased the pathogen exposure, leading to delayed mortality.

At the onset of infection, oysters acclimated to different salinities showed major differences in growth, but their levels of OsHV-1 DNA and viral gene expression after $2 \mathrm{~d}$ were similar. Therefore, it seems that the growth rate of oysters did not influence OsHV-1 replication. This result may appear somewhat paradoxical with the idea that the host cell machinery modulates the replication of herpes viruses (Lyman \& Enquist 2009). More fundamental information on the physiology of the host with respect to viral infection is needed. For instance, the impact of oyster growth conditions on their susceptibility to the virus and on the rate of virus proliferation has never been studied.

Differences in oyster survival at 15, 25 and 35\% with similar levels of OsHV-1 DNA and viral gene expression may reflect differences in bacterial communities. Indeed, several non-pathogenic bacteria contribute to the mortality of oysters (Lemire et al. 2015), and salinity is a major factor shaping the bacterial community in marine ecosystems (Herlemann et al. 2011, Dupont et al. 2014).

Estuaries and coasts, the natural habitats of oysters, are generally subject to wide fluctuations in salinity. However, salinities lower than $15 \%$ occur for only a few hours or days under natural field conditions in France (Fig. 1). Therefore, it appears that oysters are rarely acclimated to low salinity in the field, and reducing disease risk by means of low salinity is unlikely.

Acknowledgements. We thank the Ifremer staff involved in oyster and algae production at Argenton, the shellfish network Resco II (http://wwz.ifremer.fr/observatoire_ conchylicole) and Sébastien Petton for processing the salinity data. We are grateful to Pierrick Le Souchu and Christian Mingant for their help with the experimental set-up and to Martin Protat, David Tamayo, Isabelle Quéau, Véronique Loiseau, Anaïs Guyon and Gaelle Richard for their help with sampling. We also thank Morgane Chalopin for helping with the RNA analyses, Gaétan Daigle for statistical advice and Marie-Agnes Travers for discussions. This work was supported by the GIGASSAT project funded by ANR-AGROBIOSPHERE No. ANR-12-AGRO-0001-01 (www.gigassat.org).

\section{LITERATURE CITED}

Andrews JD, Wood JL (1967) Oyster mortality studies in Virginia. VI. History and distribution of Minchinia nelsoni, a pathogen of oysters, in Virginia. Chesap Sci 8:1-13

> Barbosa Solomieu V, Renault T, Travers MA (2015) Mass mortality in bivalves and the intricate case of the Pacific oyster, Crassostrea gigas. J Invertebr Pathol 131:2-10

Ben-Horin T, Bidegain G, Huey L, Narvaez DA, Bushek D (2015) Parasite transmission through suspension feeding. J Invertebr Pathol 131:155-176

Brothers C, Marks E, Smolowitz R (2000) Conditions affecting the growth and zoosporulation of the protistan parasite QPX in culture. Biol Bull (Woods Hole) 199:200-201

Burreson EM, Ragone Calvo LM, Lapeyre JF, Counts F, Paynter KT (1994) Acute osmotic tolerance of culturedcells of the oyster pathogen Perkinsus marinus (Apicomplexa, Perkinsuda). Comp Biochem Physiol A Physiol 109:575-582

Carregosa V, Velez C, Soares A, Figueira E, Freitas R (2014) Physiological and biochemical responses of three Veneridae clams exposed to salinity changes. Comp Biochem Physiol Part B Biochem Mol Biol 177-178:1-9 
Cordova A, Deserno M, Gelbart WM, Ben-Shaul A (2003) Osmotic shock and the strength of viral capsids. Biophys J 85:70-74

Cox DR (1972) Regression models and life tables. J R Stat Soc Ser B Stat Methodol 20:187-220

Davison AJ, Trus BL, Cheng NQ, Steven AC and others (2005) A novel class of herpesvirus with bivalve hosts. J Gen Virol 86:41-53

> Dupont CL, Larsson J, Yooseph S, Ininbergs K and others (2014) Functional tradeoffs underpin salinity-driven divergence in microbial community composition. PLOS ONE 9:e89549

EFSA AHAW (European Food Safety Agency Panel on Animal Health and Welfare) (2010) Scientific opinion of the Panel on Animal Health and Welfare on a request from the European commission on the increased mortality events in Pacific oysters Crassostrea gigas. EFSA J 8: 1894-1953

EFSA AHAW (2015) Oyster mortality. EFSA J 13:4122

$>$ Ford SE, Haskin HH (1988) Comparison of in vitro salinity tolerance of the oyster parasite, Haplosporidium nelsoni (MSX) and hemocytes from the host, Crassostrea virginica. Comp Biochem Physiol A Physiol 90:183-187

Ford SE, Scarpa E, Bushek D (2012) Spatial and temporal variability of disease refuges in an estuary: implications for the development of resistance. J Mar Res 70:253-277

Gilles R (1972) Osmoregulation in three molluscs: Acanthochitona discrepans (Brown), Glycymeris glycymeris (L.) and Mytilus edulis (L.). Biol Bull (Woods Hole) 142:25-35

Haskin HH, Ford SE (1982) Haplosporidium nelsoni (MSX) on Delaware Bay seed oyster beds - a host-parasite relationship along a salinity gradient. J Invertebr Pathol 40: 388-405

Herlemann DP, Labrenz M, Jürgens K, Bertilsson S, Waniek JJ, Andersson AF (2011) Transitions in bacterial communities along the $2000 \mathrm{~km}$ salinity gradient of the Baltic Sea. ISME J 5:1571-1579

Kaplan EL, Meier P (1958) Nonparametric estimation from incomplete observations. J Am Stat Assoc 53:457-481

Knowles G, Handlinger J, Jones B, Moltschaniwskyj N (2014) Hemolymph chemistry and histopathological changes in Pacific oysters (Crassostrea gigas) in response to low salinity stress. J Invertebr Pathol 121:78-84

Kukkaro P, Bamford DH (2009) Virus-host interactions in environments with a wide range of ionic strengths. Environ Microbiol Rep 1:71-77

Lassudrie M, Soudant P, Nicolas JL, Fabioux C and others (2015) Interaction between toxic dinoflagellate Alexandrium catenella exposure and disease associated with herpesvirus OsHV-1 $\mu$ Var in Pacific oyster spat Crassostrea gigas. Harmful Algae 45:53-61

Lee ET, Wang JW (2013) Statistical methods for survival data analysis. Encyclopedia Life Science. John Wiley \& Sons, Hoboken, NJ

- Lemire A, Goudenege D, Versigny T, Petton B, Calteau A, Labreuche Y, Le Roux F (2015) Populations, not clones, are the unit of Vibrio pathogenesis in naturally infected oysters. ISME J 9:1523-1531

Lin DY, Wei LJ, Ying Z (1993) Checking the Cox model with cumulative sums of martingale-based residuals. Biometrika 80:557-572

Liu B, Yu ZM, Song XX, Guan YQ, Jian XF, He JF (2006) The effect of acute salinity change on white spot syndrome (WSS) outbreaks in Fenneropenaeus chinensis. Aquaculture 253:163-170
Lucas W (2001) Viral capsids and envelopes: structure and function. Encyclopedia Life Science. John Wiley \& Sons, Chichester

Lyman MG, Enquist LW (2009) Herpesvirus interactions with the host cytoskeleton. J Virol 83:2058-2066

Matozzo V, Marin MG (2011) Bivalve immune responses and climate changes: Is there a relationship? Invertebr Surviv J 8:70-77

Miossec L, Allain G, Arzul I, Francois C, Garcia C, Cameron A (2009) First results of an epidemiological study on oyster (Crassostrea gigas) mortality events in France during summer 2008. ISVEE XII-International Symposium on Veterinary Epidemiology and Economics, Durban, South Africa

> Mojica KDA, Brussaard CPD (2014) Factors affecting virus dynamics and microbial host-virus interactions in marine environments. FEMS Microbiol Ecol 89:495-515

$>$ Neufeld DS, Wright SH (1996) Response of cell volume in Mytilus gill to acute salinity change. J Exp Biol 199: 473-484

Pepin JF, Riou A, Renault T (2008) Rapid and sensitive detection of ostreid herpesvirus 1 in oyster samples by real-time PCR. J Virol Methods 149:269-276

Pernet F, Tamayo D, Petton B (2015) Influence of low temperatures on the survival of the Pacific oyster (Crassostrea gigas) infected with ostreid herpes virus type 1. Aquaculture 445:57-62

> Pernet F, Lupo C, Bacher C, Whittington RJ (2016) Infectious diseases in oyster aquaculture require a new integrated approach. Philos Trans R Soc Lond B Biol Sci 371: 20150213

> Petton B, Pernet F, Robert R, Boudry P (2013) Temperature influence on pathogen transmission and subsequent mortalities in juvenile Pacific oysters Crassostrea gigas. Aquacult Environ Interact 3:257-273

> Petton B, Boudry P, Alunno-Bruscia M, Pernet F (2015a) Factors influencing disease-induced mortality of Pacific oysters Crassostrea gigas. Aquacult Environ Interact 6: 205-222

Petton B, Bruto M, James A, Labreuche Y, Alunno-Bruscia M, Le Roux F (2015b) Crassostrea gigas mortality in France: the usual suspect, a herpes virus, may not be the killer in this polymicrobial opportunistic disease. Front Microbiol 6:686

Pierce SK, Greenberg MJ (1972) The nature of cellular volume regulation in marine bivalves. J Exp Biol 57: 681-692

> Ragone Calvo LM, Walker JG, Burreson EM (1998) Prevalence and distribution of QPX, Quahog Parasite Unknown, in hard clams Mercenaria mercenaria in Virginia, USA. Dis Aquat Org 33:209-219

- Reid HI, Soudant P, Lambert C, Paillard C, Birkbeck TH (2003) Salinity effects on immune parameters of Ruditapes philippinarum challenged with Vibrio tapetis. Dis Aquat Org 56:249-258

> Renault T, Arzul I, Lipart C (2004) Development and use of an internal standard for oyster herpesvirus 1 detection by PCR. J Virol Methods 121:17-23

Saulnier D, De Decker S, Haffner P, Cobret L, Robert M, Garcia C (2010) A large-scale epidemiological study to identify bacteria pathogenic to Pacific oyster Crassostrea gigas and correlation between virulence and metalloprotease-like activity. Microb Ecol 59:787-798

Schikorski D, Renault T, Saulnier D, Faury N, Moreau P, Pepin JF (2011) Experimental infection of Pacific oyster 
Crassostrea gigas spat by ostreid herpesvirus 1: demonstration of oyster spat susceptibility. Vet Res 42:27

Segarra A, Pepin JF, Arzul I, Morga B, Faury N, Renault T (2010) Detection and description of a particular Ostreid herpesvirus 1 genotype associated with massive mortality outbreaks of Pacific oysters, Crassostrea gigas, in France in 2008. Virus Res 153:92-99

Segarra A, Faury N, Pépin JF, Renault T (2014) Transcriptomic study of 39 ostreid herpesvirus 1 genes during an experimental infection. J Invertebr Pathol 119:5-11

Shumway SE (1977) Effect of salinity fluctuation on osmotic pressure and $\mathrm{Na}^{+}, \mathrm{Ca}^{2+}$ and $\mathrm{Mg}^{2+}$ ion concentrations in hemolymph of bivalve molluscs. Mar Biol 41: 153-177

Shumway SE, Gabbott PA, Youngson A (1977) Effect of fluctuating salinity on the concentrations of free amino acids and ninhydrin-positive substances in the adductor muscles

Editorial responsibility: Megan La Peyre,

Baton Rouge, Louisiana, USA of eight species of bivalve molluscs. J Exp Mar Biol Ecol 29:131-150

Soudant P, Chu FLE, Volety A (2013) Host-parasite interactions: marine bivalve molluscs and protozoan parasites, Perkinsus species. J Invertebr Pathol 114:196-216

Tamayo D, Corporeau C, Petton B, Quere C, Pernet F (2014) Physiological changes in Pacific oyster Crassostrea gigas exposed to the herpesvirus OsHV-1 $\mu$ Var. Aquaculture 432:304-310

> Vezzulli L, Pezzati E, Stauder M, Stagnaro L, Venier P, Pruzzo C (2015) Aquatic ecology of the oyster pathogens Vibrio splendidus and Vibrio aestuarianus. Environ Microbiol 17:1065-1080

Webb SC, Fidler A, Renault T (2007) Primers for PCR-based detection of ostreid herpes virus-1 (OsHV-1): application in a survey of New Zealand molluscs. Aquaculture 272: 126-139

Submitted: June 13, 2016; Accepted: July 31, 2016 Proofs received from author(s): September 6, 2016 